\title{
Negotiation of Gender Relations Meaning among Female Interpretation Community in Housing and Village Settlement
}

\author{
Sri Budi Lestari ${ }^{1 凶}$, Suhartono Wiryopranoto ${ }^{2}$, GR Lono Lastoro Simatupang ${ }^{2}$ \\ ${ }^{1}$ Communication Department, Diponegoro University, Indonesia \\ ${ }^{2}$ Cultural and Media Studies, University of Gadjah Mada, Indonesia
}

Permalink/DOI: http://dx.doi.org/10.15294/komunitas.v6i2.3270

Received : July 2014; Accepted: August 2014; Published: September 2014

\begin{abstract}
The sitcom of Husbands fearing Wives (SSTI-Suami-Suami Takut Istri), is one of the private television sitcoms which highlights violence as a joke to provoke laughter of its audiences. In SSTI, the joke involves the concept of gender, exchanging the role of women and men which has been socially and culturally constructed. One of the main objectives of this study is to analyze the role of the interpretation community in understanding the gender relations in SSTI sitcom. The study aims to discover the media interpretation by a group offemale audiences living in the village and sub-district of Tembalang, Semarang. The results show that the negotiation of interpretation community on SSTI sitcom is not in line with the goal of the media; because the nature of men and women roles that are exchanged is interpreted as an "abnormal" relation. Therefore, the hierarchical power relation between men and women which tends to disadvantage women, for interpretation community is regarded as a normal $\mathcal{E}$ natural.
\end{abstract}

\begin{abstract}
Abstrak
Tayangan sinetron komedi Suami-suami Takut Istri (SSTI), merupakan salah satu program televisi swasta yang menonjolkan kekerasan sebagai lelucon untuk tujuan memancing tawa. Dalam prakteknya SSTI melibatkan konsep jender, yang mempertukarkan sifat-sifat perempuan dan laki-laki sebagai hasil kontruksi secara sosial maupun kultural. Salah satu tujuan penelitian ini ingin menganalisis peran komunitas interpretasi dalam pemaknaan tentang relasi jender pada tayangan sinetron SSTI. Penelitian ini berlangsung pada penonton perempuan yang tinggal di perumahan dan perkampungan wilayah kecamatan Tembalang, kota Semarang. Hasil penelitian menunjukkan bahwa negosiasi komunitas interpretasi pada tayangan sinetron SSTI tidak sejalan dengan arahan media karena ternyata sifat laki-laki dan perempuan yang dipertuarkan dimaknai sebagai relasi yang tidak 'normal'. Dengan demikian relasi kuasa hirarkis antara laki-laki dan perempuan yang cenderung merugikan perempuan bagi komunitas interpretasi justru dianggap sebagai suatu relasi yang normal serta dipahami sebagai kodrat kultural.
\end{abstract}

Keywords: interpretive communities; meaning

How to Cite: Lestari, S.B., Wiryopranoto, S., \& Simatupang, G.R.L.L. 2014. Negotiation of Gender Relations Meaning of Female Interpretation Community in Housing and Villages Groups. Jurnal Komunitas, 6(2): 189196. doi:http://dx.doi.org/10.15294/komunitas.v6i2.3270

(C) 2014 Semarang State University. All rights reserved 


\section{INTRODUCTION}

Television, with its audio-visual strength and creativity, is a persuasive media which can influence the emotions of the audiences. However, television has not yet been able to deliver a quality program and responsible education, information, and entertainment such as the "Husbands fearing Wives' sitcom (SSTI). This striping show was broadcasted by Trans-TV some time ago and relatively received controversial responses in society. As for the controversy, the sitcom's content involves the controlling and dominating wives, bringing the concept of gender role that seems to try breaking the patriarchal ideology; on the other hand, this sitcom is the best program of Trans-TV, with a stable rating \& TV share. The data voice consumers in 2008 mentioned that SSTI was well received in 10 major cities in Indonesia and according to the Report of Title top 100 programs of all channels, is included in the 5 best comedy show and attracting the viewers of women aged 40 years old and over from the middle socio-economic society (AGB Nielsen Survey).

Different picture is shown by Foundation for Science and Aesthetics (SET), Tifa, and Indonesian Television Journalists Association (IJTI). Their studies conducted in 2009 put SSTI sitcom in the second rank out of 5 worst program. KPI put also placed this sitcom in the category of red light because they did not pay attention to the norms of decency and morality. The show also features some scenes of violence in the household and full of harsh words, is regarded as less worthy impressions, and not suitable to be broadcasted on family show times.

This study aims to investigate the perception of some women who watch SSTI, specifically their favorite reasons in viewing that show. The question is how they construct the meaning of gender role (both in terms of family or society context) which seems to try broking down the patriarchal ideology. This question is interesting to be further examined considering the fact that their interpretation toward the meaning of television content which they consume will play a significant role in understanding the concept of gender relations.

Study of gender is indeed an interesting topic to observe. The previous studies on the 'SSTI' sitcom which have been conducted show that the dominance of women is represented and exploited to preserve the ideology of patriarchal system by presenting a negative power of pseudo-female domination and not as a rule that generates respect for female power. The power of women which is negatively constructed in a form of domestic violence depicts the logical consequence of negative construction upon the image of women in power and still maintains a positive image of men. Therefore, the patriarchal ideology is still preserved (Habsari, et al, 2011: 256-268).

Another study on SSTI sitcom is conducted by Nurul Aminati (2010) which tries to investigate the acceptance of housewife on housewife domination at the SSTI sitcom. The acceptance of housewife in Surabaya states that in terms of story theme, the sitcom is different from the common sitcoms. The difference is on the phenomenon which concerns about the husbands who are scared of their own wives. The existence of gender ideology which forms the structure of patriarchal culture puts the position of women lower than men in many areas of life including household. When the wife is more dominant in a household as described by SSTI, the role of husband is considered to be failed.

From the previous studies, it can be concluded that the aspect of media content is interesting to be investigated from perspective of audience. This study overviews the audience from their social status aspect which are demographically different. This study also aims to analyze how the media content in the family and social contexts observed through interpretation community will give a different meaning of the gender relation. This study is a qualitative study. The study is subjective and the result is casuistic or not to be generalized. Through the use of appropriate methods of reception analysis suggested by Ien Ang thought, this study wants to show that the texts of media will acquire meaning only at the time of re- 
ception which is when the text is read, seen, and heard by the readers or audiences. Ien Ang believes that the audiences are producer of meaning, not just consumers of media content. They decode or interpret media texts in a way that relates to their social and cultural experiences in their environment. From this perspective, the researchers of reception have begun studying the different ways in which groups of diverse audiences interpret the same media texts. Their interest is not directed at individual ways in solely understanding the text, but the interpreting the social and cultural meaning.

\section{METHODS}

The approach or method used in this qualitative research is the reception analysis. Reception analysis tries to uncover the various interpretations of the media content by a small number of audiences or readers. This research was conducted in Tembalang village, Semarang.

Subjects were selected according to the criteria referring to the AGB Nielson recommendations in newsletters published in 2009, that the major audiences of SSTI sitcom are women, aged over 40 years old from middle class society. The selection of respondents was based on the previous studies in which the majority female audience liked a sitcom (fiction, soap operas).

The selection of the middle class group in this study is based on the opinion of Dick Howard (1996: 69) who argues that Indonesia's middle class can be identified through how they consume commodities and exercise their different lifestyle. Mahasin splits the criteria of the middle class people in the village (poor) and city (rich) groups (1996: 69). Therefore, the criteria of this research subject are not only for women who have watched and able to retell SSTI sitcom but also those who are from the middle social class which have different consumption patterns and lifestyles. Besides aiming to obtain the diversity of subjects in the study, such criteria limitation is selected because it will also affect the subject's ability to understand, interpret and receive the SSTI sitcom that they had ever seen.
This study will also analyze how audiences interpret texts represented by TV media as a producer of SSTI sitcom. The process will be observed through an ethnographic method which aims to observe how the practice of consumption when the audiences watch the show and how they, in their capacity as viewers, interpret television material of social context and situation of consumption practices in different types of family. Similarly, this study tries to reveal how fellow audience members who gather as an interpretation community can take role in establishing the meaning of the texts by the media.

\section{RESULTS AND DISCUSSION}

Understanding sitcom refers to a genre (style) of comedy show based on the social situation and can easily be identified by audiences because the repeated broadcasting. Its orientation which explores the life of home, workplace, and other public locations as well as its funny and satirical packaging makes the sitcom as a genre which can last long in his native country, United States (Danesi, 2009: 271). SSTI sitcom can be categorized as an impression sitcom program, especially if judging by the above statement from Danesi. Therefore, in addition to meet the criteria of the genre, this sitcom also focuses on the social situation background about the household life. The show is different from the other shows because this sitcom which is originally considered only as an entertainment involves the concept of gender. The sitcom tries to break down the common notion that masculine role is not always associated with power, aggression, and strength. And the feminine attitude is not always associated with weak, timid, and dependent on others. The role of women and men who are socially and culturally constructed is actually a trait that can be exchanged. When viewing the phenomenon at a glance, the existence of this comedy seems to be able to break the patriarchal culture that always puts women as subordinate; but when we examine more deeply, the SSTI sitcom also depicts female subordinates, which is shown from the fact that out of many women who become wi- 
ves, there is only one woman who works in public sector (Deswita). This also implies a picture if women only dwell in the domestic affairs. The dominant and arbitrary power of wives is deliberately highlighted in this show, so that the women representation as a subordinate figure does not become the audience's attention. In certain cultures, it is explained that women who show masculine characteristics are not real women (Tong, and Donchin 2004: 51), as the description in this show suggests. Hence, the SSTI sitcom can be interpreted indirectly as a description of a negative thing because although the role and position have been exchanged, the presence of women in this sitcom is far from the ideal character of many women, because when women work into the public domain or they are able to be equal with her husband does not mean that they will later become a frightening and oppressive figure toward men. The idea is depicted in the SSTI which is very different from the fact of most Indonesian family that embraces the culture of patriarchy. However, there is the funny humor from the sitcom.

\section{Negotiations in the context of the fam- ily on village and housing respondents}

Negotiation in this context is the starting point related to the audience in interpreting the meaning of the media content. In the Dictionary of Media Studies, it is mentioned that negotiation is a process of compromise between the readings offered by the text (the media) and assuming the reader's own interpretation (2006: 156). Similarly, in the Dictionary of Media and Communication (Danesi, 2009: 210), it is stated that the negotiations in this discussion is associated with negotiated reading, which is an interpretation of the text as a result of a compromise process between the manufacturer reading text with the preferred text by the readers. Therefore, it can be said that in the process of negotiating the text meaning here is more focused on the text recipients. As proposed by Ang who sees that the audiences are the producers of meaning, not just consumers of media content, so that the meaning of the text is very relative to the reader, i.e. when the text is read and seen by the media audiences.

The negotiation process that takes place in the housing inforrmants toward the picture of media produces the same concept of in understanding comedy. The comedy has always been associated as funny and humorous. The notion can be observed from the background of their underlying meaning upon humor in the concepts of comedy which are closely linked to the social context of the family from different environments. The reality here is in line with the emphasis from Ien Ang who states the audiences as producers of meaning. The audiences can interpret media texts through its relationship with the social, cultural, as well as their experiences with their social environment. The audiences are active in giving meaning to the text of media. Therefore, it is natural if they also have different reactions when they watch some programs in the media.

The negotiation process between concepts of comedy that is offered by media for village respondents is line with the image received by housing respondents. They both agree upon the concept of humor that is always attached to comedy shows. In the group of village respondents, the interpretation of funny humor is more focused on gestures (action) of the actors.

All information related to the underlying picture reception become the foundation of respondents' answers from both housing and village respondents toward the concept of funny humor. This situation can be interpreted as an irony because things that are usually interpreted as a humor is generally interpreted in addition to the discrepancy between the words and the behavior broadcasted by media and the real life. It usually depicts the unreasonable or ridiculous happenings. Things that do not make sense generally based on the differences in the social context of the family and neighborhood of respondents. Therefore, this notion establishes the sense of humor for them. 
Negotiation within the social context of the housing and villages respondents.

Negotiation discussed in this study is related to the social context at the time when the respondents interpret the content of SSTI sitcom. The interpretation of meaning appears in a form of audience response to talk about SSTI sitcom with their friends in their work, considering the majority of housing respondents work in the public sector. In the respondents' work, the SSTI show is discussed as a joke between friends as well as a distraction talks when they take a break. The conversation later becomes the mockery topic addressed to their peers who are considered to resemble the characters of the sitcom casts, including their good attitudes, appearances, and speaking manner. The mockery eventually becomes permanent nickname for their friends. Negotiation process in the picture reception that takes place in this group can be interpreted in accordance with the direction of media who deliberately feature humor through each female character on the show. Media representation can be said to be in line with the social context of the respondents as the audience. On the other hand, the social context is also able to direct the audience to agree with the media direction that is still showing a picture of subordinate women in SSTI sitcom.

The discussion about SSTI sitcom is interpreted as the mockery about the reality of life in big cities which happens relatively frequent. The picture of the situation on the SSTI sitcom according to the respondents' view is possibly inspired by the social context that occurs in the real community. The emergence of interpretation which relates satire/mockery is a new television genre that is displayed on the television screen so that the image removed from this reality can also be regarded as one of the key success of this sitcom. The discussion of the social context is continued when the respondents criticize the lack of precise broadcasting hour during prime time because the schedule may disturb the worship time for Muslim audiences.

The majority of village respondents, who are mostly housewives, discuss SSTI sitcom focusing on the violence against husband's wives in every episode of this sitcom. The negotiation of respondents can be said as not in line with the description offered by the media, where media puts the violence as a humor source of this sitcom. That violence also triggers another concern not only on children's audience, but also in the actors of the sitcom in which some of them are still children of primary school age. However, they are also involved in the displayed violence. The emergence of the respondents' fear is possibly based on the different interpretation of children, especially if the show is interpreted as a common affair both in the contexts of family and social environment.

\section{Negotiation of meaning of gender rela- tions in the context of family}

Negotiation which is taking place in the context of housing respondents' families can be said as "not in line" with the picture shown by the SSTI sitcom. The media tries to put an idea of interchangeable characters of women and men who have been socially and culturally constructed and make it as a source of humor. However, the respondents actually accept the idea as an "unnatural and highly exaggerated" picture. Social and cultural factors in the respondents' families are very influential on their understanding. It brings the consequences of respondent being lack of understanding with the media goals. Based on respondents' understanding with their own context of families, gender relations that have been built since the beginning of marriage is based on the cooperation, connection, and support toward each others' respective roles that have been agreed in the family, as it is revealed in the finding of Reeves and Baden (2000: 10). Although the role agreement that has been built since the early marriage brings consequences for women who work outside the house, they do not mind to receive the double burdens (after the household and work). This reality is regarded as part of a normal and natural consequence. Fakih in Sugihastuti and Ithna Hadi Setiawan (2007: 279) argues that the existence of reality like this shows the gender inequality impacts the 
injustice actions against women. In this study, the respondents unwittingly contribute in an attempt to strengthen this situation, because the unequal role is not interpreted as gender injustice against women, but rather interpret as a cultural nature.

The media overview upon the existence of women in SSTI sitcom for the housing respondents is far away from the ideal character of women. Their statement is based on the experience of working in the public sector since the beginning of their housekeeping jobs. When they work in the public sector, it does not mean that later they want to become a figure that wants power or oppresses men. As stated by Tong and Donchin (2004: 51) that in certain cultures, women who show masculine characteristics are not real women.

The interpretation of gender relations within the family context in the village is more various. There are informants who interpret gender relations as relations between men and women; if the relationship is applied in the context of family, it can be defined as an equal relationship between a husband and a wife. Other respondents regard this relation as a relationship which is not about winning a victory between husband and wife, but a balanced relationship according to their respective roles. Besides those meanings, gender relation is also interpreted as the relationship between women and men that have been defined for generations where men serve as heads of households and women serve as housewives. This variation of the heterogeneous interpretations is interesting to observe, especially if it is associated with the social context on eah family. The respondents' social context of family in the village is different from the previous group, especially considering the education background as well as their daily activities. The majority education of village informants is high school graduates and their daily activities as a housewife bring an understanding that their responses only focus on the equal relationship - a relationship that is not winning a victory between husband and wife and the relationship of men and women who have dealt with hereditary various roles. In observational research, these statements indicate the understanding of the village respondents toward gender relations still holds the expectations and hopes of a balanced relationship between women and men while on one of the respondents there is a belief that the existing relationship between men and women is one relation that has been defined for generations, hence should be followed as her predecessors.

The media picture in SSTI sitcom which shows the roles exchange of men and women merely to provoke laughter is understood by the village respondents as the media goal. But each respondent refuses if the role of the exchange occurs in the context of everyday life. The existence of refusal on media representations through SSTI sitcom shows that the process of negotiations between the respondents with the media is not consistent. The gender role has been constructed socially and culturally by observing the respondents' statements during the study that "the husband as head of the family should be respected, especially as the family financial seeker". Similarly, their statements that "parents always teach that women as wives are obliged to respect their husband as the head of the family". The relation between men and women in their interpretation is not a relationship which should win a victory on each other and the role they play is a role that has been assigned for generations. From some of the above respondents' answers, it can be interpreted that without them knowing, gender relation in which they live indicates a contribution to strengthen the hierarchical power relations between men and women who tend to disadvantage women. The fact that they accept it as a natural relation is in accordance with Reeves and Baden (2000: 10) who state that the hierarchical division of roles between men and women is understood as a normal relation which is formed socially and culturally and may change from time to time.

\section{Negotiation of meaning of gender rela- tions in the interpretation community} In the context of interpretation communi- 
ties, housing respondents interpret gender relation as a mutual interaction that occurs between a husband - a wife in a family. Interaction is characterized by the interdependence and solidarity between the two sides. Gender relation in the SSTI sitcom by interpretation community is interpreted as an artificial relationship because of the absence of reciprocal interaction between husband and wife where one of the main parties is more powerful than their partner (in this case is the wife). An unequal position between husband and wife according to their perspective is not able to create a reciprocal interaction. The negotiation process that takes place in the interpretation community of SSTI sitcom supports the findings in the family context, which can also be said not in line with the media goal.

On one side, the media wants to show the women not as a subordinate by exchanging the role and position of men and women, but this source of humor is interpreted differently by different groups of interpretation community. Interpretation community of housing group actually interprets the relation which is depicted by media as an abnormal relation (pseudo relationship, not real). For them, the existence of hierarchical power relations between men and women that tend to harm the women are considered as a normal and real relationship. According to Fakih in Sugihastuti and Ithna Hadi Setiawan (2007: 278), the impact of gender inequality on women injustice position finally is claimed as a cultural nature. The respondents also believe that the picture in SSTI sitcom is inspired by the social context in which the show is produced, although the picture in accordance with SSTI the relatively few which is broadcasted. The interpretation community in housing group questions the existence of gender inequality as a cultural nature, especially by those who are literate or educated. This opinion is based on their knowledge about the rise of feminist movement that demands gender equality between men and women or between husband and wife in the last decade. This kind of information does not become a problem for women who are only primary education graduates or no education at all because for them, the hierarchical position between women and men which are actually a form of gender inequity are interpreted as a normal condition and has been hereditary passed over generations. The condition is also understood as the norm in their social and cultural context.

Different statements expressed when the respondents in the village join the interpretation community in which they actually support the SSTI sitcom in exchanging the roles between men and women. This exchange of role is understood as a moment of inspiration that can happen when the husband figure shown in SSTI sitcom occurs in the context of their family life. The wives who go against their husbands shown in the SSTI sitcom is regarded as a reasonable behavior within the interpretation community because they constitutes a persistent willingness to maintain the integrity of their household. The idea is also supported by the experience owned by one of the interpretation community members that they support the behavior of women in SSTI sitcom although they did not agree at first.

The support of interpretation of community can be regarded as sublimation which is the experience of respondents in a non-verbal language. Kramarae states that non-verbal language is said to have the power relations embedded in it, and there are power relations as an expression of the language. The view of Kramarae in the understanding of researcher can be analogized as sublimation which is one of the main forms of non-verbal expression shown by female members of the interpretation community. According to Freud's thought that is published in Bertens (2006: 65), sublimation can be defined as desire and behavior transfer that can be accepted by the norms of society. The form of 'power' which is displayed by the female characters in the SSTI sitcom can be interpreted as sublimation which takes place on the interpretation community respondents for their behavior and desire transfer to be accepted by the norms of society. However, it can also be said that the state is an expression of their non-verbal responses as 
an impact that they are silenced, as stated by Kramarae in Littlejohn, Foss (2008: 116).

\section{CONCLUSION}

The family and social context sources in the process of interpretation are essential in establishing the meaning of the informants in the housing and village. The interpretation of community also contributes a significant impact in the process of formation of gender relations. This fact is especially shown in the interpretation of the village community; if the meaning of gender relations in the SSTI sitcom is initially not agreed by the respondents as they are inconsistent with their family and social context, the situation becomes different when the interpretation is in the context of the interpretation community. The power relation in their everyday life is strongly influential to support the interpretation community in establishing the meaning of gender relation.

\section{REFERENCES}

Barker, C. 2009. Cultural Studies, Teori dan Praktik. Penerjemah: Nurhadi. Yogyakarta: Kreasi wacana.

Bertens, K. 2006. Psikoanalisis Sigmund Freud. Jakarta: Penerbit Gramedia Pustaka Utama.

Danesi, M. 2009. Dictionary of Media and Communi- cations. NewYork: Copyright by M.E. Sharpe, Inc 80 Business Park Drive, Armonk.

David, M. 2005. Family Television: Cultural Power and Domestic Leisure. London: Taylor \& Francis eLibrary.

Downing, J., Mohammadi, A. \& Mohammadi, A.S. 1990. Questioning The Media: A Critical Introduction. California: Sage Publication.

Habsari, S.K., Primasita, F.A., \& Al-Makmun, M.T. 2011. Representasi Dominasi Perempuan dalam Rumah Tangga: Analisis Tekstual Terhadap Situasi Komedi (Sitkom) "Suami-Suami Takut Isteri”. Jurnal Humaniora. 23 (3): 256268.

Littlejohn, S.W. \& Foss, K.A. 2008. Theories of Human Communication, ninth edition, USA: Thomson Wadsworth, Publishing Company.

Nugroho, R. 2011. Gender dan Strategi Pengarus Utamaannya di Indonesia, cetakan ke II. Yogyakarta: Pustaka Pelajar.

Reeves, H. and Baden, S. 200o. BRIDGE-development gender, Gender and Development: Concepts and Definitions, report no. 55, Institute of Development Studies University of Sussex.

Street, J. 2001. Mass Media, Politics and Society. New York: Palgrave.

Sugihastuti \& Setiawan, I.H. 2007. Gender dan Inferioritas Perempuan. Yogyakarta: Penerbit Pustaka Pelajar.

Tester, K. 2003. Media, Budaya dan Moralitas. Yogyakarta: Juxtapose Tester.

Tong, R. \& Donchin, A. 2004. Linking Visions: Feminist Bioethics, Human Rights, And The Developing World, Rowman and Littlefield.

Dictionary of Media Studies. 2006. A \& C Black. London. 